\title{
Local Political Parties in an Age of Change
}

John P. Frendreis and Alan R. Gitelson, Loyola University, Chicago

Few American political institutions have prompted as much research, controversy, and debate during the post-World War II era as have political parties. In turn, few institutions have seen their demise (Broder 1971; Sundquist 1982; Crotty 1984; Wattenberg 1990, 1991) and, alternately, their rejuvenation (Schlesinger 1985; Kayden and Mahe 1985; Pomper 1981; Price 1984; Gitelson, Conway, and Feigert 1984) reported so often in scholarly publications, textbooks, and the popular press. Gibson and his colleagues suggested in 1985 that "[t]he last twenty years have not been kind to American political parties" $(1985,139)$, and, as we approach the twenty-first century, many scholars would agree that the past four decades have been marked by a volatile and changing party system.

Tracking the history and evolution of the modern party organization is hindered by the realization that most of the considerable contemporary research on parties focuses on electoral behavior rather than party structure. In turn, a substantial and significant portion of the academic scholarship (as well as journalistic attention) on party structure has focused on national (Cotter and Hennessy 1964; Conway 1983; Schlesinger 1985; Bibby 1986) and state party organizations (Key 1956; Huckshorn 1976; Cotter et al. 1984; Epstein 1986; Paddock 1990).

While we have learned much in recent years about the new and changing nature of party organizations at the state and national level (with most of the research pointing to the growing role of the national and state party organizations [see, e.g., Herrnson 1990 and Bibby 1990]), far less attention over the past three decades has been directed to the study of local party organizations in their multiple roles of organization building, fundraising, recruitment and de-recruitment, getting-out-the-vote, campaign coordination, and patronage.

This is not to suggest, as we shall shortly see, that this field has been void of research, for a number of scholars have been responsible for providing us with significant insights and findings regarding local party

JOHN P. FRENDREIS is Professor of Political Science at Loyola University, Chicago. ALAN R. GiTELSON is Professor of Political Science at Loyola University, Chicago.

The American Review of Politics, Vol. 14, Winter, 1993: 533-547

(C)1993 The American Review of Politics 
organizations. But given the continuing rapid change in the role of party organizations in general, the need to regularly assess and revise the state of knowledge about local political party organizations is obvious. Once the focal point of considerable research, the study of local party organizations has, for too long, been relegated to a minor role compared to the study of national and state party organizations.

This article focuses on local party organizations, assessing the current state of knowledge and outlining the most important areas for future research. The article is organized to sequentially address five questions: what do we know about local political party organizations in the United States? What are the most important areas in which our knowledge is inadequate? How might this research void be addressed? What are some of the potential findings which might be obtained? What are the consequences for American democracy of the changes which have occurred or are likely to occur in the form and functions of local political party organizations?

\section{Current Knowledge About Local Party Organizations}

\section{Research Before 1980}

Since the turn of the century, few aspects of local party politics have received greater attention than that of "the machine," a term first used in Moisei Ostrogorski's seminal 1902 work, Democracy and the Organization of Political Parties. Ostrogorski's research described the local party machine as constituting the "absolute power of the small cliques of managers, who settled everything behind the scenes." They were, according to Ostrogorski's early observations, "an aggregation of individuals stretching hierarchically from top to bottom, bound to one another by personal devotion, but mercenary, and bent solely on satisfying their appetites by exploiting the resources of a political party" (Ostrogorski 1902, 422-423).

Research has repeatedly chronicled the prevalence of local machine party politics in the United States during the first half of the 19th century and well into the first half of the 20th century, thriving in many urban and rural communities into the late 1960s (Mayhew 1986). As Crotty succinctly put it, "The machine aspect of American politics is the most written about, the best recorded, and the most romanticized in U.S. political history" (Crotty 1991a, 1155). Indeed, a great share of the pre-1980 scholarship on local party organizations focuses on the party-organization-as-machine.

The research of Peel (1935), Gosnell (1937), Meyers (1937), Banfield and Wilson (1963), Dorsett (1968), Callow (1970), Wolfinger (1972), and Rakove (1975) represents only a small part of the collective research on 
machine politics in the 20th century. ${ }^{1}$ Scholars argued that the machine represented the best and the worst of the political parties, alternately assimilating, socializing, and providing needed services to new immigrants and the downtrodden, overcoming a fractionalized federalist system of government, and mobilizing voters, while at the same time corrupting the political system through patronage, preferments, and a variety of abuses of public office. Much of the debate over the utility of machine politics centers around the ultimate contribution that the machines made to the development of urban government. While more recent work on urban machines has sought to track the continuing evolution of these organizations (e.g., Guterbock 1980), the bulk of the research on urban machines is, for all intents and purposes, dated.

The pre-1980 era of research on local parties extended beyond the study of machine politics. A number of researchers sought to identify the electoral consequences of county and sub-county (e.g., precinct-level) party activity, including Cutright and Rossi (1958), Katz and Eldersveld (1961), Wolfinger (1963), Cutright (1963, 1964), and Crotty (1971). The common result of these studies was to find moderate relationships between party activity and electoral outcomes. A typical example was the work of Eldersveld, who studied political parties in Wayne County (Detroit). He identified a number of functions considered critical to the success of local party organizations, including programmatic activity and get-out-the-vote efforts (Eldersveld 1964; Katz and Eldersveld 1961). This work also led Eldersveld to develop the important concept of a "stratarchy," the idea that party organizations were best understood as decentralized and independent of each other, at times cooperative, but not hierarchial. In addition, while noting that party efforts in Wayne County did lead to increased votes at election time, Eldersveld also raised questions about the efficiency of local party organizations and their capacity to contribute to voter mobilization and choice. $^{2}$

Prior to 1980 almost all research on party organizations below the state level were case studies with little generalizeability (for an exception see Crotty 1971). Important questions were generated, and a number of relevant theories were tested as to their applicability to the viability and operation of local party organizations. In addition, with the exception of Crotty's 1971 article, all of the work documented party activity from the 1950s and early 1960 s, a period that pre-dated much of the perceived decline in local and other party organizations. With popular and scholarly accounts advancing the thesis of party decline, the stage was set for the beginning of the contemporary period of research into the structure and activity of local parties. 


\section{The Post-1980 Era of Local Party Organization Research}

The 1980s marked an important resurgence in the study of local party organizations. The central focus for most of these studies has been the measurement and analysis of the viability of local party roles and functions - the classic question of whether parties matter. In light of the considerable literature that was generated over the past two decades describing party organizations as going through a significant decline in role and function, the work of Cotter, Gibson, Bibby, Huckshorn, Frendreis, and Vertz at the county level, and Crotty, Eldersveld, Marvick, Hopkins, Murray, Tedin, Lawson, Pomper, and Moakley at the municipal and metropolitan level was critical in redefining our understanding of the viability of local party structures.

The point-work for this new generation of research was initially undertaken in the Cotter, Gibson, Bibby, and Huckshorn Party Transformation in the United States and the Institutional Party project, the most systematic and broad-based research study generated in this century to examine state and local party structures (Cotter et al. 1984; Gibson et al. 1985). Their 1984 research concluded that local party organizations, in responding to a changing political environment, did sustain a fairly high level of programmatic activity and that their findings "[di]d not support the thesis of party decline" so popularly touted by other scholars $(1984,57)$. In an article published in 1985 , these authors argued that county parties continued to sustain a high level of activity during both election and nonelection years and that such activity was independent of the strength of state party organizations, "despite the fact that state party organizations give substantial quantities of assistance to local parties" (Gibson et al. 1985, 155). A significant finding of the Gibson et al. research was that the strength of party organizations is independent of the strength of the party-in-the-electorate and the party-ingovernment.

Two important conclusions about local party organizations were derived from this body of research. First, while the roles and functions of local county party organizations may have changed over the past three decades, local party organizations remain a fundamental actor in the political process. This finding directly challenged the demise of the political party organization thesis.

The second conclusion, also of significant importance, was a challenge to Eldersveld's theory of "stratarchy." The authors argued that the party structure at the national, state, and local levels were far more integrated than

Eldersveld's model suggests, a position also supported by the later work of Gibson, Frendreis, and Vertz (1989). While this finding may be an artifact 
of the time differences in the two studies, by the 1980s, while party structure in the United States was not strictly speaking hierarchial, it was increasingly organizationally integrated.

Based on a later survey of the Party Transformation Study county organizations, Frendreis, Vertz, and Gibson found additional evidence that local county party organizations were involved in electorally relevant activities, "including candidate recruitment, joint planning with candidate organizations, and various independent campaign activities" (1990, 225). These authors concluded that county party organizations are active and independent political institutions and that party organizations do have an effect on electoral politics. As we approach the twenty-first century, party transformation is not synonymous with party decline.

Some of the conclusions of the Cotter et al. work have not gone unchallenged. Lawson, Pomper, and Moakley (1986), examining local party organizations in twenty-five New Jersey communities in Middlesex County, took issue with Cotter and his colleagues regarding the prevalence of party organizational stratarchies. Incorporating Downs and Olson rational-choice modeling into their research model, Lawson et al. argued that Eldersveld's party decision making model of a stratarchy was confirmed in their research. Further research on this subject may be necessary to confirm or reject the Cotter et al. findings although those conclusions, also supported by Frendreis, Gibson, and Vertz (1990), are grounded in a far broader-based sample of party activists than the Lawson, Pomper, Moakley research. A separate analysis of the New Jersey setting by Pomper (1990) questioned the electoral relevance of local party activity. The work of Lawson and her colleagues, however, does seem to confirm the Party Dynamic Project findings that local party leaders "seek and get electoral linkage with the political process" and that those leaders are "active and they direct their activism into electoral campaigns" (Lawson, Pomper, and Moakley 1986, 367).

While contemporary research on local party organizations at the municipal level is not extensive, several studies examining urban party organizations, in addition to that of Lawson et al. serve as a link with the earlier work of Eldersveld and others. Reporting their research findings in a volume edited by William Crotty (1986), the authors addressed the question of the vitality, organization, and operation of urban party organizations in Houston (Murray and Tedin), Nashville (Hopkins), Detroit and Los Angeles (Eldersveld), Los Angeles (Marvick), and Chicago (Crotty).

While these five case-studies are multifaceted and cover considerable ground regarding the life of local party activists and organizations, the research suggests some speculative answers to the question of party decline at the local level. Focusing on three campaign related activities-voter 
registration, door-to-door canvassing, and election day get-out-the-vote drives - Crotty concludes, "based on the results in these five cities . . . that the local parties are active in critical areas of campaigning, that they appear to be principal actors in the electoral process, and that there is no evidence of an atrophying of party activity or organization" (Crotty 1986, 30). Eldersveld, in a longitudinal analysis comparing the findings from his pioneering study on Detroit party organizations in 1964 with his research in 1986, concluded that "these data do not really support the contention that there has been a decline in local party activities in the past twenty-five years" (Eldersveld 1982, 147, quoted in Crotty 1986, 30).

This brief overview indeed suggests that the research agenda on local party organizations has been a fruitful one. Clearly, it has also been an agenda that in recent years has attracted very limited attention and resources from scholars working in the general field of party organization research. Many of the findings remain, surprisingly, untested in other county and municipal environments. There is a need for us to turn our attention to a broad-based research agenda for local party organizations.

\section{A Research Agenda Regarding Local Party Organizations}

\section{Gaps in Our Knowledge}

In the introduction to his 1986 book, Crotty developed a thirteen-point list of "the types of data needed in order to assess the operations, relevance, and contributions of local parties" (Crotty 1986, 19). Many of these data were directed toward understanding today's party activists - their social characteristics, political background, career pathways, motivations, attitudes toward government, issue positions, and attitudes toward campaigning. Other needed information dealt with the activities of party organizations, the interactions among local parties, state and national parties, and non-party electoral actors, and the relationship between party organizations and the larger social and political environment.

At the time, Crotty noted that most of these data were neither available nor likely to become available anytime soon. Seven years later, this gloomy assessment seems equally apt. A review of the tables of contents of both general interest political science journals and interdisciplinary urban studies journals reveals few articles devoted to an understanding of local political parties. If this trend continues, research into local parties may become a "lost world," to use Herson's (1957) famous phrase.

As a supplement to Crotty's list of necessary but missing data, we would add four basic research questions which we feel are the most pressing 
elements in the unmet research agenda. The most important of these questions is: In what ways are local party organizations changing during this age of change for parties and elections? The need in this regard is for more than replication of earlier work in new settings and time frames. Rather, there is a clear and pressing need for more systematic longitudinal research.

During the last thirty years there have been major changes in campaign finance, campaign technology, and the statutory environment in which parties operate. Yet, with some very limited exceptions (e.g., Eldersveld 1986) we have little genuinely comparable data about party organizations that span the same period. A few additional studies have monitored party organizations and party activists over shorter periods, roughly from the late 1970s through the mid-1980s (see Marvick 1986; Gibson, Frendreis, and Vertz 1989). While we cannot go back in time in order to understand the changes which have already occurred, it is essential that the research community begin the systematic collection of longitudinal data on local party organizations so that their continued evolution can be monitored and understood.

A second basic research question that needs to be addressed is: What is the electoral role of contemporary local parties, particularly in regard to sub-congressional races? Although scholars in this area are generally dubious of claims that the parties are electorally irrelevant, there is little hard evidence that directly addresses the electoral role of local parties in an age of candidate-centered campaigning. Perhaps the best known recent study is Herrnson's (1986), which focuses on the role of parties in congressional races, where it is clear that party organizations, while not irrelevant, are less significant than candidates' own organizations and actors such as PACs and campaign consultants (see also Kazee and Thornberry 1990). However, there is good reason to suspect that the role of local parties is greater for more local races, such as county races or state legislative races (Frendreis, Gibson, and Vertz 1990; although see also Pomper 1990). The traditional lore concerning urban machines stresses their concern for control of local offices, and more contemporary studies reveal that local party chairs' own perceptions are that their organizations are most relevant with regard to these lower level races (Gibson, Frendreis, and Vertz 1989). The vast majority of elected offices in the United States are state and local offices representing sub-state constituencies, and there is little contemporary knowledge of the electoral relevance of local parties for these offices. For both theoretical and practical reasons this must be an important target of ongoing research.

A third pressing research question is: What is the relationship between local party organizations and other electoral actors, such as interest groups, PACs, and campaign consultants? There is some evidence that state and 
national parties have adapted to the new electoral environment and serve crucial brokerage functions, bringing candidates and these important actors together. A similar role may be played by local parties, especially for more local offices, yet little is known of this facet of local political life.

Finally, a fourth important research question about which little is known is: What are the post-electoral connections of local parties with office-holders? It is apparent to even casual observers that contemporary parties do not command the loyalty of office holders in the way that powerful urban machines are thought to have done in the past. Yet it is equally apparent that elected officials invest significant amounts of their time-even after the election-building and retaining their ties to party activists and party leaders. Research is needed that describes, first, the nature of this interaction and, second, the implications of this interaction for the formulation and implementation of public policy.

\section{Promising Research Strategies}

Considering the limited amount of research dealing directly with local parties that is currently underway, additional research on all phases of local party activity would be welcome. Beyond this, we would like to suggest three specific research strategies as being particularly promising. Although our focus in this article is on local parties, much of what we are proposing has equal force with regard to state parties.

We believe the most significant strategy for advancing our knowledge about local political parties - as well as the most costly — would be the establishment of a continuous monitoring project for local (and other) party organizations. The major component of such a project would be the collection of comparable data at regular intervals measuring the structural attributes and activities of local party organizations. The starting point for such work would be the extensive effort by Cotter and his colleagues in the Party Transformation Study (PTS) to identify the structural attributes and programmatic activities of all state and local parties in 1980 (Cotter et al. 1984). There have already been two limited extensions of the PTS work at the local level. Gibson, Frendreis, and Vertz (1989) resampled about 600 of the major PTS party organizations in 1984. More recently (1992), the two authors of this review surveyed the chairs of all the Democratic and Republican county organizations in eight states (as well as the major party candidates for the state legislature in these states); we will begin to report on the substantive results of this project at the 1993 APSA meeting (Frendreis et al. 1993). 
Each of these studies provides a valuable longitudinal dimension, but both are limited by sampling decisions and in time. For example, all three efforts to measure PTS attributes have occurred during presidential election years. Our view is that the research community should undertake a biennial survey of state and local party organizations, with the results being generally available through the ICPSR. There is clear precedent for the collaborative development of such a collective resource, e.g., the National Election Study (NES) series and the recent effort of the judicial politics community to extend and regularly update the Supreme Court Judicial Database. The widespread usage of the PTS party organizational strength measures demonstrates the potential usefulness of such data, should it become available.

We are not, however, suggesting that the PTS be replicated every two years. Again, using the NES strategy as a model, a biennial survey of state and local parties could essentially contain two types of questions, selected measures of structural attributes and organizational attributes asked every two years and a second set of questions unique to each survey designed to probe distinct (and changing) research questions. Our initial proposal would be to survey the universe of state and local party organizations ${ }^{3}$ for at least two election cycles - presidential and mid-term - to establish a national baseline of data. Beyond this point, practical considerations (e.g., cost and the possibility of declining response rates due to oversampling) may dictate surveying samples rather than the universe, although periodic resurveys of the universe would still be needed to estimate the attributes of specific local organizations at particular points in time.

A second type of systematic longitudinal data collection that should be undertaken is the regular surveying of local party activists, including party officials, local candidates, and other electoral actors. The model for this research is the work of Marvick (1986), who has established an extensive database through the biennial surveying of local activists in Los Angeles since 1968. Data such as these directly address many of the lacunae enumerated by Crotty (1986). What is needed here is another collaborative effort to establish similar long-term projects in a number of other settings - in states with a variety of statutory and political cultural environments, in smaller as well as larger counties, and in suburban "collar counties" as well as counties containing large central cities.

In addition to developing more systematic longitudinal research, a second research strategy we would propose is to develop a clearer focus on local races and officeholders. A greater focus on these lower-level offices is warranted for three reasons. First, as we noted above, local party leaders themselves believe their organizations are most relevant and effective with regard to lower-level offices. Second, lower-level offices, such as state 
legislative and county offices, are responsible for public policy that is substantively important and collectively represents hundreds of billions of dollars in annual expenditures. Third, what happens at these levels is relevant for electoral and partisan politics at higher levels. We would argue, for example, that the continued incomplete development of the Republican party in many parts of the South is more a function of what has or has not happened at the local level than it is of national and state-wide politics (e.g., see Frendreis, Gibson, and Vertz 1990, 231-232).

A third promising research strategy is to systematically integrate research on local political parties with research on legislative and executive politics at the state and local level. Insofar as research has sought to connect local party organizations and party activity with other political arenas, the general focus has (understandably) been on the connection with campaigns and elections (e.g., Cutright and Rossi 1958; Katz and Eldersveld 1961; Wolfinger, 1963; Crotty 1971; Frendreis, Gibson, and Vertz 1990; Pomper 1990). However, an accurate portrayal of the role of local parties in American politics requires an understanding of how party politics is manifested between elections, both among office holders and between office holders and the broader cadre of party activists and contributors.

Given the costs, would projects such as these-including the major collaborative longitudinal efforts we have argued are necessary-represent a sensible investment of scholarly resources? The answer, we feel, rests upon how much credence the scholarly community attaches to Crotty's observation of "the indispensability of a party system to an operating democracy" (1991b, 140). In most parts of the United States it is impossible to meaningfully discuss electoral, legislative, or executive politics at the state or local level without reference to political parties. Yet, the level of knowledge about these key institutions is remarkably less than what we know of voters, governmental budgets, or the inner workings of the U.S. Congress. It may well be that local (and other) political parties are becoming increasingly irrelevant in the various spheres of U.S. politics. Given our present knowledge base, however, our current assessments of the role of local parties in American politics are, at best, incomplete, and more commonly, little more than informed guesses.

\section{Local Political Parties and American Democracy}

Political parties perform a number of significant functions in an "operating democracy." First, parties mobilize, stimulate, and provide structure to mass participation. Although other institutions may also perform these functions, parties are clearly the dominant institutions in these areas in most 
democratic systems. Second, parties often organize the substance of political debate. Third, parties recruit candidates for elective office, and more generally, holders of public offices. Finally, parties organize and mobilize elite deliberations, including the coordination of executive and legislative activity.

In some respects, this listing of critical functions of political parties may seem more normative than descriptive when applied to American political parties, particularly at the local level. However, even in American politics, the activities of Democratic and Republican organizations and, less tangibly, the power of Democratic and Republican views of the proper role of government, are in evidence throughout the range of American political life.

The American federal structure has meant that a vertically divided governmental structure has been paralleled by a party system of loosely-coupled national, state, and local organizations. Local parties presumably perform each of the functions identified above, but with a more local focus. Local parties also may perform the distinctive function of being a training ground for party and electoral activity at higher levels of government. If, however, American parties continue an apparent trend toward increasing integration (Cotter et al. 1984), local parties may become less autonomous actors, despite the federal structure of American politics.

Although parties perform a variety of roles, the electoral role is key, since political parties that cannot control entry into political office-or, less strongly, assist the efforts of ambitious politicians to gain office-are likely to play only limited roles with regards to the non-electoral aspects of politics, such as the organization of political debate or the development of public policy. Indeed, an ability to influence the outcomes of elections is an element in almost every attempt to define the term political party (e.g., see the discussion by Sartori 1976, 58-64). It is precisely this aspect of partisan life - the electoral role-in which American political parties are thought to be most at risk in the current age of change.

The view we have expressed above is that the limited amount of contemporary research precludes us from knowing with any certainty the actual electoral role of today's parties, particularly at the local level. Additional research may reveal a number of trends in the continuing evolution of American parties; for simplicity we identify three possibilities. First, American parties may be evolving into "responsible parties" of the type advocated long ago by the American Political Science Association (1950). Clearly there is little evidence of movement in this direction, although the increasing organizational strength of many party organizations, coupled with signs of increasing vertical integration of national, state, and local organizations may enhance the capacity of parties to influence electoral politics. However, in the absence of basic changes in nomination procedures, there is little 
likelihood that parties can reassert the control over office-holders they exercised in earlier periods of American history.

A second possible outcome is what might be called the disintegrating model, in which parties continue to lose influence over candidates and voters. Some research suggests that this is the case, particularly research on the hold parties exercise over the long-term loyalties of voters (e.g., Wattenberg 1990). In addition, it is apparent that the dominant campaign style today for major offices (e.g., president, governor, U.S. Senator, and U.S. Representative) is for candidate-centered electoral coalitions rather than for party-run campaigns; however, without further research, it is premature to assume the wholesale extension of this phenomenon to more local races. Research from a variety of perspectives shows little direct relationship between local party activities and local voting outcomes (Huckfeldt and Sprague 1992; Pomper 1990; Frendreis, Gibson, and Vertz 1990); still unknown is the precise electoral role of local parties with regard to other key electoral activities, such as candidate recruitment and support, voter registration, and the coordination of interest group activity.

A third possibility might be termed the adaptive brokerage model. In this view, local parties (as well as national and state parties) have adapted to changes in the electoral environment, developing new roles, particularly the role of bringing together candidates, consultants, and contributors. The specific role of political parties varies according to the electoral context. Where a party has been historically weak, the local party organizationaided by state and national organizations - may play a broader role in recruitment and direct electioneering. Local parties also may play a similar role for relatively low visibility races where the extent of the candidatecentered coalition is the candidate and a few close friends and family members. In more competitive areas and for higher visibility races, where candidate self-selection is the norm, adaptive brokerage parties would deliver resources to candidates - money, volunteers, newly registered voters - while the candidates themselves would be expected to deliver the votes. This view of parties as adaptive organizations was the view of the PTS researchers (Cotter et al. 1984) and seems to reflect the intuitions (and hopes) of many other party scholars.

This article must end where it began, with uncertainty over the current state and likely future of local political parties. Practically, the key unanswered research question is whether local parties are closer to the disintegrating model or the adaptive brokerage model; while the responsible parties model falls closest to the normative prescriptions of democratic theory, it is clearly distant from the actual functioning of American parties. Democratic theory is not neutral with regard to the other two possibilities, 
however. While adaptive brokerage parties may be less than perfect vehicles for the organization of political debate and the development of public policy, the alternative - electorally irrelevant parties - are wholly inadequate to the requirements of American politics. Thus the need to better understand the evolving form and functions of local and other parties is more than a scholarly imperative; it is a practical necessity.

\section{NOTES}

${ }^{1}$ A 1978 bibliography of case studies of bosses and machines, for example, listed over 50 book-length case studies published between 1912 and 1975. See Dilldine et al. (1978).

${ }^{2}$ For example, while Katz and Eldersveld (1961) found a relationship between Republican activity and the 1952 presidential vote, they found no relationship between Democratic activity and the 1952 vote.

${ }^{3}$ Although our focus in this article is on local party organizations, we are suggesting the survey of state and local organizations because the activities of the two are becoming sufficiently connected that a complete understanding of local parties requires knowledge of the state party context, as well.

\section{REFERENCES}

American Political Science Association. 1950. Toward a More Responsible Two Party System. New York: Rinehart.

Banfield, Edward C. and James Q. Wilson. 1963. City Politics. New York: Vintage.

Bibby, John F. 1990. Party Organization at the State Level. In L. Sandy Maisel, ed., The Parties Respond: Changes in the American Party System. Boulder, CO: Westview Press.

1986. Political Party Trends in 1985: The Continuing but Constrained Advance of the National Party. Publius 16: 90.

Broder, David S. 1971. The Party's Over: The Failure of American Parties. New York: Harper and Row.

Callow, Alexander B., Jr. 1970. The Tweed Ring. New York: Oxford University Press.

Conway, M. Margaret. 1983. Republican Party Nationalization, Campaign Activities, and Their Implications for the Political System. Publius 13: 1-17.

Cotter, Cornelius P., James L. Gibson, John F. Bibby, and Robert J. Huckshorn. 1984. Party Organizations in American Politics. New York: Praeger.

and Bernard C. Hennessy. 1964. Politics Without Power: The National Party Committees. New York: Atherton Press.

Crotty, William. 1991a. Urban Political Machines. In L. Sandy Maisel, ed., Political Parties \& Elections in the United States: An Encyclopedia, vol. 2. New York: Garland.

1991b. Political Parties: Issues and Trends. In William Crotty, ed., Political Science: Looking to the Future, Vol. Four: American Institutions. Evanston, IL: Northwestern University Press.

, ed. 1986. Political Parties in Local Areas. Knoxville: University of Tennessee Press.

1984. American Parties in Decline. Boston: Little, Brown. 439-450.

1971. Party Effort and Its Impact on the Vote. American Political Science Review 65: 
Cutright, Phillips. 1964. Activities of Precinct Committeemen in Partisan and Non-Partisan Communities. Western Political Quarterly 17: 93-108. . 1963. Measuring the Impact of Local Party Activity on the General Election Vote. Public Opinion Quarterly 27: 372-386. and Peter Rossi. 1958. Grass Roots Politicians and the Vote. American Sociological Review 63: 171-179.

Dilldine, David A., et al. 1978. A Bibliography of Case Studies of Bosses and Machines. Monticello, IL: Vance Bibliographies.

Dorsett, Lyle W. 1968. The Pendergast Machine. New York: Oxford University Press.

Eldersveld, Samuel J. 1964. Political Parties: A Behavioral Analysis. Chicago: Rand McNally. . 1986. The Party Activist in Detroit and Los Angeles: A Longitudinal View, 19561980. In William Crotty, ed., Political Parties in Local Areas. Knoxville: University of Tennessee Press.

Epstein, Leon D. 1986. Political Parties in the American Mold. Madison: University of Wisconsin Press.

Frendreis, John P., Alan R. Gitelson, Gregory Flemming, and Anne Layzell. 1993. Political Parties and the 1992 Campaign for the State Legislature. Paper presented at the annual meeting of the American Political Science Association, Washington, DC.

Frendreis, John P., James L. Gibson, and Laura L. Vertz. 1990. The Electoral Relevance of Local Party Organizations. American Political Science Review 84: 226-235.

Gibson, James L., Cornelius P. Cotter, John F. Bibby, and Robert J. Huckshorn. 1985. Whither the Local Parties? A Cross-Sectional and Longitudinal Analysis of the Strength of Party Organizations. American Journal of Political Science 29: 139-160.

Gibson, James L., John P. Frendreis, and Laura L. Vertz. 1989. Party Dynamics in the 1980s: Change in County Party Organizational Strength, 1980-1984. American Journal of Political Science 33: 67-90.

Gitelson, Alan R., M. Margaret Conway, and Frank B. Feigert. 1984. American Political Parties: Stability and Change. Boston: Houghton Mifflin.

Gosnell, Harold F. 1937. Machine Politics: Chicago Model. Chicago: University of Chicago Press.

Guterbock, Thomas M. 1980. Machine Politics in Transition. Chicago: University of Chicago Press.

Herrnson, Paul S. 1990. Reemergent National Party Organizations. In L. Sandy Maisel, ed., The Parties Respond: Changes in the American Party System. Boulder, CO: Westview Press.

1986. Do Parties Make a Difference? The Role of Party Organizations in Congressional Elections. Journal of Politics 48: 589-615.

Herson, Lawrence. 1957. The Lost World of Municipal Government. American Political Science Review 51: 330-346.

Hopkins, Anne H. 1986. Campaign Activities and Local Party Organization in Nashville. In William Crotty, ed., Political Parties in Local Areas. Knoxville: University of Tennessee Press.

Huckfeldt, Robert and John Sprague. 1992. Political Parties and Electoral Mobilization: Political Structure, Social Structure, and the Party Canvass. American Political Science Review 86: 7086.

Huckshorn, Robert J. 1976. Party Leadership in the States. Amherst: University of Massachusetts Press.

Katz, Daniel and Samuel Eldersveld. 1961. The Impact of Local Party Activity upon the Electorate. Public Opinion Quarterly 25: 1-24.

Kayden, Xandra and Eddie Mahe, Jr. 1985. The Party Goes On. New York: Basic Books.

Kazee, Thomas A. and Mary C. Thornberry. 1990. Where's the Party? Congressional Candidate Recruitment and American Party Organizations. Western Political Quarterly 43: 61-80.

Key, V. O., Jr. 1956. American State Politics: An Introduction. New York: Knopf.

Lawson, Kay, Gerald Pomper, and Maureen Moakley. 1986. Local Party Activists and Electoral Linkage: Middlesex County, NJ. American Politics Quarterly 14: 345-375. 
Marvick, Dwaine. 1986. Stability and Change in the Views of Los Angeles Party Activists, 19681980. In William Crotty, ed., Political Parties in Local Areas. Knoxville: University of Tennessee Press.

Mayhew, David R. 1986. Placing Parties in American Politics. Princeton, NJ: Princeton University Press.

Meyers, Gustavus. 1937. The History of Tammany Hall. New York: Modern Library.

Murray, Richard W. and Kent L. Tedin. 1986. The Emergence of Two-Party Competition in the Sunbelt: The Case of Houston. In William Crotty, ed., Political Parties in Local Areas. Knoxville: University of Tennessee Press.

Ostrogorski, Moisei. 1902. Democracy and the Organization of Political Parties. New York: Macmillan.

Paddock, Joel. 1990. Beyond the New Deal: Ideological Differences Between 11 State Democratic Parties, 1956-1980. Western Political Quarterly 43: 181-190.

Peel, Roy V. 1935. The Political Clubs of New York City. New York: Putnam's.

Pomper, Gerald M. 1990. Party Organization and Electoral Success. Polity 23: 187-206. , ed. 1980. Party Renewal in America. New York: Praeger.

Price, David E. 1984. Bringing Back the Parties. Washington, DC: Congressional Quarterly Press.

Rakove, Milton. 1975. Don't Make No Waves . . . Don't Back No Losers. Bloomington: Indiana University Press.

Sartori, Giovanni. 1976. Parties and Party Systems: A Framework for Analysis, Vol 1. Cambridge: Cambridge University Press.

Schlesinger, Joseph A. 1985. The New American Party System. American Political Science Review 79: 1152-1169.

Sundquist, James L. 1982. Party Decay and the Capacity to Govern. In Joel Fleishman, ed., The Future of American Political Parties. Englewood Cliffs, NJ: Prentice Hall.

Wattenberg, Martin P. 1991. The Rise of Candidate-Centered Politics. Cambridge: Harvard University Press.

1990. The Decline of American Political Parties: 1952-1988. Cambridge: Harvard University Press.

Wolfinger, Raymond E. 1972. Why Political Machines Have Not Withered Away and Other Revisionist Thoughts. Journal of Politics 34: 365-398.

1963. The Influence of Precinct Work on Voting Behavior. Public Opinion Quarterly 27: 387-398. 
